Saudi Journal of Business and Management Studies Abbreviated Key Title: Saudi J Bus Manag Stud ISSN 2415-6663 (Print) IISSN 2415-6671 (Online) Scholars Middle East Publishers, Dubai, United Arab Emirates Journal homepage: https://saudijournals.com/sjbms

Original Research Article

\title{
Knowledge Management Infrastructure Capabilities and Innovativeness of Small and Medium Scale Enterprises in Benue State, Nigeria
}

\author{
James Tersoo Tsetim ${ }^{1 *}$, Ochanya Blessing Adegbe ${ }^{2}$ and Richard Jimin Agema ${ }^{2}$
}

${ }^{1}$ Department of Business Administration, College of Management Sciences, Federal University of Agriculture, Makurdi, Benue State, Nigeria

${ }^{2}$ Department of Business Management, Faculty of Management Sciences, Benue State University, Makurdi, Nigeria

DOI: $10.36348 /$ sjbms.2020.v05i03.006

| Received: 16.03.2020 | Accepted: 23.03.2020 | Published: 27.03.2020

*Corresponding author: James Tersoo Tsetim

\section{Abstract}

The contemporary business environment in Benue state, Nigeria demands all Small and Medium Scale Enterprises (SMEs) irrespective of which sector they operate in to innovate in order to secure a place in the market, and Knowledge Management (KM) infrastructure is said to be one of the strategies with which firm innovativeness can be promoted. It is in view of this that this study was conducted to examine the relationship between KM infrastructural capabilities and innovativeness of SMEs in Benue state, Nigeria. The study adopted the survey design. The population for this study consisted of 1370 employees from 14 SMEs in Benue State. The research focused only on SMEs with up to 50 employees. These SMEs were selected from the three business hubs in the state (Makurdi, Gboko and Otukpo) which covers all the geo-political zones of the State. This number cut across business activities like manufacturing, food processing, bakery, table water, schools, hoteling and ICT. Through purposive sampling technique, Five hundred and eighteen (518) employees from the selected SMEs (i.e. 37 from each) made up the sample size for the study. A selfadministered-adopted questionnaire was employed to collect quantitative data for hypothesis testing. Five hundred and eighteen (518) questionnaires were issued out to the respondents however, only four hundred and forty five (445) responses validly retrieved and included in analysis. Data were statistically analyzed after being collected from the field with the aid of Statistical Package for Social Sciences (SPSS, v. 21). Pearson Correlation Analysis was employed in determining the relationship between the independent variables (technological, cultural and structural infrastructures) and the dependent variable (SMEs innovativeness). Multiple regression analysis on the other hand tested the extent of effect of independent variables on the dependent variable at 0.05 level of significance. The result of Pearson Correlation Analysis revealed that all the infrastructural dimensions (technology, culture and structure) significantly relate with SMEs Innovativeness. The result of multiple regression analysis showed a higher effect of cultural infrastructural dimension followed by technology and structure with a low effect though positive. Therefore, it is recommended among others that SMEs need to double their support for the use of technological facilities and develop the desired trainings for the operation of technological facilities.

Keywords: Knowledge Management, Knowledge Management capabilities, Knowledge Management infrastructure capabilities, Culture, Structure, Technology, Small and Medium Scale Enterprises, Innovativeness, Benue state, Nigeria.

Copyright @ 2020: This is an open-access article distributed under the terms of the Creative Commons Attribution license which permits unrestricted use, distribution, and reproduction in any medium for non-commercial use (NonCommercial, or CC-BY-NC) provided the original author and source are credited.

\section{INTRODUCTION}

Small and Medium Scale Enterprises (SMEs) operating in today's global dynamic business environment must develop a virile Knowledge Management capabilities that support innovativeness which endeared organizations to respond to recurring changes in the business environment and sustain competitive advantage. In respect to the fast pace with which changes are occurring in the world, and radical competition, business entities, especially SMEs are Required to make adequate inputs to renew their processes and products to enhance their economic status and attain competitive advantages [1]. To achieve this, SMEs must be innovative. Being Innovative has been accepted as a significant enabler of economic growth 
[2]. Innovation has come to be the pillar of today's firms, and it is found to impact positively on organizational competitiveness and effectiveness [3].

The centrality of Knowledge Management $(\mathrm{KM})$ as a key element in innovation is overwhelmingly upheld [4]. Knowledge is observed as a key strategic resource, that demands special attention, and the innovation capability of SMEs is a factor of their ability to absorb knowledge from external and internal sources [5]. $\mathrm{KM}$ is found to be the best instrument to develop the strategic capabilities for SMEs to survive in the current dynamic and competitive economy [6]. It has become a vital performance factor for success of innovative economy [7].

$\mathrm{KM}$ is a strategy for managing organizational knowledge as a strategic resource and harnessing processes such as creation, acquisition, storage, sharing and dissemination, retrieval and use of tacit and explicit knowledge $[8,7]$. However, sustaining a comprehensive knowledge management process depends on the presence of knowledge management capabilities [9].

$\mathrm{KM}$ capabilities consist of KM infrastructure capability and KM processes capability $[10,11]$. KM infrastructure capability is a collective environment (technology, culture and structure) through which firms achieve the effective execution of actions related to KM and supports key operational and innovative activities $[10,12,13]$. KM infrastructure capabilities support KM process of acquisition, conversion, application and protection of knowledge through integration of resources and activities that encourage innovativeness which is leverage to competitive advantage [14].

Innovation and creativity is widely viewed as a necessity for survival in the current competitive business arena and organisations are spending so much on $R \& D$ to stay competitive [15]. On the part of SMEs, their survival remedy is consistent innovation. SMEs innovativeness is an intentional change in their existing products, services, ideas and operations new to the end user or unit of adoption [16]. This involves developing SMEs with the ability to process information such that the result is new, original and meaningful [17]. SMEs are often thought to have a greater potential to innovate than do their larger counterparts. This is largely because as small firms grow, it is necessary that they introduce new products, processes, and management changes and acquire new systems, all of which can be viewed as innovativeness [18].

Small and Medium Enterprises (SMEs) remains one of the most important category of business activities of the Nigerian economic structure [19]. They play an important role in increasing production, generating employment, improving revenue, enhancing income, and advancing creativity and technological progress. SMEs' shares could reach $(75 \%)$ of economic activity in many countries [19]. Previous researches have shown the significant contribution of innovation and innovative strategies on performance of SMEs [20]. Thus, it can be said that innovation, if explored and exploited judiciously has the potential to produce optimal benefits for SMEs. This study is therefore undertaken to examine how knowledge management infrastructural capabilities can enhance SMEs innovativeness in Benue State.

\section{Conceptual clarifications, literature review and hypotheses formulation \\ Knowledge Management}

$\mathrm{KM}$ is a process of identifying and analyzing accessible knowledge that is needed to achieve organizational objectives [21]. This means it is the process through which organizations generate value from their intellectual and knowledge-based assets [22]. Nevertheless, organizations need to institute KM capabilities in order to generate value from their intellectual and knowledge-based assets [19]. Knowledge management capabilities refer to organizational mechanisms that continuously create knowledge and encourage the acquisition, storing, protecting, and sharing of knowledge in organiza-tions [23, 19]. KM capabilities come in two forms: infrastructural capabilities and process capabilities. KM infrastructural capabilities consist of technology, structure and culture [10, 24, 25, 9], while KM process capabilities refers to acquisition, creation, refinement, storage, transfer, sharing, and utilization [26, 27]. This study however, concentrates on KM infrastructural capabilities.

\section{Knowledge Management Infrastructure Capabilities The term "knowledge management} infrastructure capability" has been mentioned in the literature as the knowledge assets or knowledge enablers [28]. It is the building blocks of KM for improvement and effectiveness of all organizational functions relating to implementation of best $\mathrm{KM}$ systems [11]. The importance of knowledge management infrastructure lies in the fact that successful implementation of knowledge management requires adequate infrastructure in the organization [9]. Knowledge management infrastructural capability create collaborative environment which push the components of KM to interact one another and becomes the facilitator between KM applications and problem solving [29, 30]. Knowledge management infrastructure is the foundation upon which knowledge management activities are constructed [27]. In this research article the authors reviewed past studies $[10,11,12,27,13,14$, 9] and considered three vital dimensions of knowledge management infrastructure capabilities; technology, culture and structure.

\section{Technology}

The application of technology has been found to be one of the most vital knowledge management 
infrastructural capabilities in every organization $[7,31$, $32,14]$. Technology infrastructure is the combination of data processing, storage, and communication technologies and systems (databases, servers, computers, information devices, etc) and the processes that make it all work [33]. It comprises the entire spectrum of organization's information systems, including transaction processing systems and management information systems, data warehouses, as well as enterprise resource planning systems [34]. The element of technology in knowledge infrastructure involves information technology systems allowing the integration of information and knowledge in the organization and providing the creation, transfer, storage and protection of knowledge resources in the organization [35].

Advances in Information and Communication Technology have led to the design of innovative knowledge-sharing environment and programs, whereby geographically individuals are virtually accessible to meet, collaborate, create and share knowledge [36]. Technology provides support for collaboration, communication between employees, searching, accessing, and systematic storing; it determines how knowledge travels throughout the enterprise [10, 37]. Zaied et al. [11] suggested that current era is the technological era and the organizations that have best technology have greater competitive edge over others. Zaied [11] proved that technology has positive effect and facilitator towards $\mathrm{OP}$ and towards implementation of KM system as well. Zaim et al. [20] found that information technology improves KM performance.

\section{Organizational culture}

Organizational culture is defined as a combination of rules, norms, values, assumptions, and beliefs that are possessed by employees within an organization, and affect how they think and make decisions [38, 39, 27]. Every organization exists with its unique culture [40]; and as such, it is vital for each organization to understand their own culture as it is likely to be setback or an infrastructural support to knowledge management and innovativeness [19]. Having an appropriate organizational culture may be a condition for the effectiveness of knowledge management [41]. This is due to the fact that if an organi-zation's culture does not readily accept change, then KM programs are doomed to fail [42].

Cultural values like consumer orientation, service quality, informality, innovation are significantly related to organizational performance $[43,35]$. An optimum organizational culture is one that embraces a culture of knowledge sharing, coordination, cooperation, and acquisition by employees [44]. An SME must focus on its values that permit employees to commit to the proper use of information in database systems for customers, suppliers, and staff [45, 46].
These practices contribute significantly to the improvement of innovation processes [33]. Therefore, it is expected that the affirmative dynamics in culture affect the ability of firms to be innovative and speed up performance in different sections of the firm [35].

\section{Organizational structure}

Organizational structure is referred to the formal division of employment functions and administrative mechanisms to keep in line and integrate work activities [43]. It is the formal allocation of work tasks, roles, responsibilities, and authorities that exist within an organization, including policies, procedures, hierarchic relationships, sector boundaries, and so on $[10,27]$. Organizational structure plays an important role in the leveraging of technology and communication networks and in facilitating the collaboration and sharing of knowledge in organizations [34, 44]. Matin and Sabagh [35] stated that change in the structure of an organization, such as movement from hierarchical forms to flatter network forms, is effective for knowledge creation and transfer. Flatter networks or horizontal organizational structure is related positively to innovativeness [35] and improved performance of the organization in both financial and service terms [47].

\section{SMEs Innovativeness}

SMEs are said to innovate more often than larger organisations [17]. This is because they are prone to growth and expansion and this demand innovativeness. There is no specific agreed definition of innovativeness. Different approaches used in explaining what innovation means gave rise to different definitions innovativeness. Innovativeness is defined as the state of creation of new knowledge and ideas to facilitate new business outcomes aimed at improving internal business processes and structures and to create market driven products and services [22]. CamisÉn and Villar-López [48] defined innovation as "the implementation of a new or significantly improved product (goods or services) or process, a new marketing method, or a new organizational method in business practices, workplace organization or external relations. Kashif et al. [49] defined innovation as the activities and processes of creation and implementation of new knowledge in order to produce new products, services and processes to meet the customer's needs and preferences in different ways as well as to make process, structure and technology more sophisticated that can bring prosperity among individuals, groups and into the entire society.

Though there are varying definitions of innovation, each of them is focused on creating change in structure, process, technology and product/services in order to satisfy the needs of customers and to gain competitive advantage. This embraces new approaches for allocating task and duties among employees, new ideas for the structuring of activities, new technology for enhancing products or processes and new approaches for decision-making [27]. Hence SMEs 
innovativeness is considered in terms of product innovation, process innovation and technology innovation. Studies have shown that SMEs innovativeness is a significant survival approach to the fierce competition in today's dynamic business environment [17, 27], SMEs organizations that do not have the capability to provide innovative products and services, are to be forced to shut down by other competitors [45].

\section{Knowledge Management Infrastructure Capabilities and SMEs Innovativeness}

This subsection reviews studies that give an insight to the relationship existing between KM infrastructure capability and SMEs innovativeness. This covered the three infrastructure capabilities (technology, culture and structure) under review as captured in the preceding paragraphs.

In respect to the technology capability, Hajir, Obeidat, Al-dalahmeh and Masa'deh [27] examine the effect of KM infrastructure capability and the result showed that there is a statistically significant impact of technology on innovation. The findings of the study by Amundsen, et al. [6] also revealed that technological tools such as information and communication technology can aid knowledge management processes, which is a significant predictor of firm's innovation potential. This is implies that using technologies to facilitate communication, interaction and flow of knowledge between different parties will enhance innovation [22]. In the same perspective, Okatan [50] attested that there is a strong relationship between ICT and innovation. Thus, this study hypothesizes that there is no significant relationship between structural KM infrastructure and innovativeness of SMEs in Benue State, Nigeria.

Okibo and Shikanda [51] analyzed the effects of organizational culture on innovation in the services industry, and the result revealed a significant relationship between organizational culture and innovation. They also suggested a total overhaul of organizational culture so as to increase the sharing of knowledge, skills and awareness in order to increase innovativeness. In another study, Hajir, Obeidat, Aldalahmeh and Masa'deh [52] found a statistically significant impact of organizational culture on innovation. Same as Kambiz and Aslan [53] who stated that organizational culture has a significant effect on organizational innovation. Other studies by Büschgens, et al. [46] and Abdullah, et al., [39] showed that it is possible to improve firm innovativeness through organizational culture. Thus this study hypothesizes that there is no significant relationship between technological KM infrastructure and innovativeness of SMEs in Benue State, Nigeria.

Varying results have been found from studies that examined organizational structure and firm innovativeness. Ho, et al. [39] argued that organisations with centralized structure limits the contributions that employees can make in performing their tasks, limits knowledge sharing, and it suppresses innovative solutions; and that it has the capacity to negatively influence firm innovativeness. On a contrary, Argyres and Silverman [54] in their findings suggest that centralization may be good for innovation, in particular by helping to increase information processing efficiency and reducing transaction costs in knowledge transfer within a firm. Hajir, Obeidat, Al-dalahmeh and Masa'deh [32] examined the impact of organizational structure on innovation in the telecommunication industry, and found a negative and insignificant impact of organizational structure on innovation. Matin and Sabagh [35] argued that decentralized organizational structure is related positively to innovativeness. Thus, this study hypothesizes that there is no significant relationship between organizational cultural KM infrastructure and innovativeness of SMEs in Benue State, Nigeria.

\section{METHODOLOGY}

The study adopted the quantitative survey design in assessing the relationship between KM infrastructural capabilities and SMEs innovativeness. The population for this study consisted of 1370 employees from 14 SMEs in Benue State. The research focused only on SMEs with up to 50 employees. These SMEs were selected from the three business hubs in the state (Makurdi, Gboko and Otukpo) which covers all the geo-political zones of the State. This number cut across business activities like manufacturing, food processing, bakery, table water, schools, hoteling and ICT. Through purposive sampling technique, five hundred and eighteen (518) employees from the selected SMEs (i.e. 37 from each) made up the sample size for this study.

A self-administered-adopted questionnaire was employed to collect quantitative data for hypothesis testing. The questionnaire was divided into two categories, with the first part measuring KM infrastructural capabilities (technological, cultural and structural infrastructures), and the second part was for measuring SMEs innovativeness (the dependent variable). The instrument for measuring technological, cultural, and structural infrastructures was adapted from Gold et al. [10], and it has been validated by Ho, et al., [39]; Lai, [55]; Zaied, [11]; and later again by Masa'deh [44]. It includes 11 items for technological $\mathrm{KM}$ infrastructure, 11 items for structural infrastructure, and 12 items for cultural infrastructure, all being 4-point Likert scale questions (with 1 meaning "strongly disagree and 4 meaning strongly agree). The instrument for measuring the "innovativeness" construct was derived from the scale first developed by Syvertsen [56]. The scale was later validated by Chuang, et al. [57] and Hung, et al., [58]. This instrument measured innovation in three dimensions; product innovation, 
process innovation and technological innovation. Again, all items are 4-point Likert scale questions, same as in $\mathrm{KM}$ infrastructure capability constructs.

A pilot study was conducted to test the accuracy and the consistency of the research instrument. The result showed that all the constructs were greater than 0.70 indicating that the measures of the variables were reliable (consistent). Five hundred and eighteen (518) questionnaires were issued out to the respondents with the help an insider assistant from each SME. Respondents were allowed to fill the questionnaires and were retrieved after 2 hours. A total of four hundred and fifty seven (457) questionnaires were retrieved from participants, making a response rate at $88.22 \%$. However, 12 responses were either incomplete or wrongly filled and so were excluded leaving only four hundred and forty five (445) responses included in analysis. Data were statistically analyzed after being collected from the field with the aid of Statistical Package for Social Sciences (SPSS, v. 21). Pearson Correlation Analysis was employed in determining the relationship between the independent variables (technological, cultural and structural infrastructures) and the dependent variable (SMEs innovativeness). Multiple regression analysis on the other hand tested the extent of effect of independent variables on the dependent variable at 0.05 level of significance.

\section{TEST OF HYPOTHESES}

The results of the data analyzed for the study were presented on the basis of the hypotheses generated for the study.

\section{Correlations Analysis}

$\mathrm{HO}_{1}$ : There is no significant relationship between technological KM infrastructure and SMEs innovativeness in Benue State, Nigeria.

Table-1: Pearson's Correlation Showing relationship between technological KM infrastructure and SMEs Innovativeness

\begin{tabular}{|c|c|c|c|}
\hline \multicolumn{4}{|c|}{ Correlations } \\
\hline & & $\begin{array}{l}\text { Technological KM } \\
\text { infrastructure }\end{array}$ & SMEs Innovativeness \\
\hline \multirow{3}{*}{$\begin{array}{l}\text { Technological KM } \\
\text { infrastructure }\end{array}$} & Pearson Correlation & 1 & $0.429 * *$ \\
\hline & Sig. (2-tailed) & & .000 \\
\hline & $\mathrm{N}$ & 445 & 445 \\
\hline \multirow[t]{3}{*}{ SMEs Innovativeness } & Pearson Correlation & $0.429 * *$ & 1 \\
\hline & Sig. (2-tailed) & .000 & \\
\hline & $\mathrm{N}$ & 445 & 445 \\
\hline
\end{tabular}

Source: Field data, 2020.

From the summary of the Pearson correlation of technological KM infrastructure and SMEs innovativeness in Table 1, the result revealed that the calculated correlation coefficient $r=0.429$ at 0.05 significant level is positive and significant. Also, the two-tailed test conducted to access the significance level of the value of correlation coefficient yields a Pvalue of 0.000 which was significant at 0.05 level. Therefore, the null hypothesis which states that technological KM infrastructure has no significant relationship with SMEs innovativeness is rejected with the conclusion that "there is a significant relationship between technological KM infrastructure and SMEs innovativeness in Benue State, Nigeria. The interpretation of this finding is that an increase in technological KM infrastructure would likely lead to about $42.9 \%$ proportional increase in SMEs innovativeness.

$\mathrm{HO}_{2}$ : There is no significant relationship between cultural KM infrastructure and SMEs innovativeness in Benue State, Nigeria.

Table-2: Pearson's Correlation showing relationship between cultural KM infrastructure and SMEs innovativeness

\begin{tabular}{|c|c|c|c|}
\hline \multicolumn{3}{|c|}{ Correlations } \\
\hline \multirow{3}{*}{$\begin{array}{c}\text { Cultural KM } \\
\text { infrastructure }\end{array}$} & Pearson Correlation & 1 & Cultural KM infrastructure \\
\cline { 2 - 4 } & Sig. (2-tailed) & 445 & $0.518^{* *}$ \\
\cline { 2 - 4 } & $\mathrm{N}$ & $0.518^{* *}$ & .000 \\
\hline \multirow{2}{*}{ SMEs Innovativeness } & Pearson Correlation & .000 & 445 \\
\cline { 2 - 4 } & Sig. (2-tailed) & 445 & 445 \\
\cline { 2 - 4 } & \multicolumn{2}{|c|}{$\mathrm{N}$} & \multicolumn{2}{c|}{} \\
\hline
\end{tabular}

Source: Field data, 2020. 
From the summary of the Pearson correlation of cultural KM infrastructure and SMEs innovativeness in Table 2, the result revealed that the calculated correlation coefficient $r=0.518$ at 0.05 significant level is positive and significant. Again, the two-tailed test conducted to access the significance level of the value of correlation coefficient yields a P-value of 0.000 which was significant at 0.05 level. Therefore, the null hypothesis which states that cultural KM infrastructure has no significant relationship with SMEs innovativeness is rejected with the conclusion that "there is a significant relationship between technological KM infrastructure and SMEs innovativeness in Benue State, Nigeria. The interpretation of this finding is that an increase in cultural KM infrastructure would likely lead to about $51.8 \%$ proportional increase in SMEs innovativeness.

$\mathrm{HO}_{3}$ : There is no significant relationship between structural KM infrastructure and SMEs innovativeness in Benue State, Nigeria.

Table-3: Pearson's Correlation showing relationship between structural KM infrastructure and SMEs innovativeness

\begin{tabular}{|c|c|c|c|}
\hline \multicolumn{3}{|c|}{ Correlations } \\
\hline \multirow{3}{*}{$\begin{array}{c}\text { Structural KM } \\
\text { infrastructure }\end{array}$} & Structural KM infrastructure & SMEs Innovativeness \\
\cline { 2 - 4 } & Pearson Correlation & 1 & $0.705^{* *}$ \\
\cline { 2 - 4 } & Sig. (2-tailed) & & .000 \\
\hline \multirow{2}{*}{ SMEs Innovativeness } & $\mathrm{N}$ & $0.705^{* *}$ & 445 \\
\cline { 2 - 4 } & Pearson Correlation & .000 & 1 \\
\cline { 2 - 4 } & Sig. (2-tailed) & 445 & 445 \\
\cline { 2 - 4 } & $\mathrm{N}$ & $* *$ Correlation is significant at 0.05 level (2-tailed). \\
\hline
\end{tabular}

Source: Field data, 2020.

As evidenced from the summary of the Pearson correlation of structural KM infrastructure and SMEs innovativeness in Table 3, the result revealed that the calculated correlation coefficient $\mathrm{r}=0.705$ at 0.05 significant level is positive and significant. Also, the two-tailed test conducted to access the significance level of the value of correlation coefficient yields a Pvalue of 0.000 which was significant at 0.05 level. Therefore, the null hypothesis which states that structural KM infrastructure has no significant relationship with SMEs innovativeness is rejected with the conclusion that "there is a significant relationship between technological KM infrastructure and SMEs innovativeness in Benue State, Nigeria. The interpretation of this finding is that an increase in structural KM infrastructure would likely lead to about $70.5 \%$ proportional increase in SMEs innovativeness.

\section{RESULT OF MULTIPLE REGRESSION ANALYSIS}

Table-4: Results of Multiple Regression Analysis

\begin{tabular}{|c|c|c|c|c|c|c|c|}
\hline Variable & $\mathbf{r}$ & $\mathbf{R}^{\mathbf{2}}$ & $\mathbf{f}$ & Sig (f) & $\mathbf{B}$ & t & Sig (f) \\
\hline Technological KM Infrastructure & \multirow{3}{*}{0.822} & \multirow{3}{*}{0.676} & \multirow{3}{*}{113.893} & \multirow{3}{*}{$0.000 \mathrm{a}$} & 0.492 & 2.548 & 0.012 \\
\hline Cultural KM Infrastructure & & & & & 0.603 & 7.756 & 0.000 \\
\hline Structural KM Infrastructure & & & & & 0.179 & 0.905 & 0.007 \\
\hline
\end{tabular}

Source: Field data, 2020.

The result in Table 4 showed that the regression coefficient, $\mathrm{R}=0.822$ indicates a positive relationship between the set of independent variables and the dependent variable. The coefficient of determination $\left(\mathrm{R}^{2}\right)$ was 0.676 and this implies that 67.6 $\%$ of the variation in SMEs Innovativeness is explained by technological, cultural, structural KM infrastructure. Table 4 also showed the standardized coefficient $(\beta$ value) for each of the KM infrastructural dimensions. The $\beta$ values (predictor coefficients) indicate the individual contribution of each independent variable to the model with the other predictors held constant. The levels of effect of these variables are represented by the $\beta$ value: the higher the $\beta$ value, the higher effect of that particular infrastructural dimension on SMEs Innovativeness. The $\beta$ values for technological and cultural infrastructures (0.492 and 0.603 respectively) are highly statistically significant, but the $\beta$ value for structural infrastructure $(0.179)$ is low though statistically significant. We conclude that cultural infrastructure has the highest effect on SMEs Innovativeness, followed by technological infrastructure, and lastly, structural infrastructure has a significant but weak effect on SMEs Innovativeness. This result indicates that a unit increase in technological $\mathrm{KM}$ infrastructure would increase SMEs Innovativeness by $49.2 \%$, a unit increase in Cultural KM infrastructure would increase SMEs Innovativeness by $60.3 \%$ and a 
unit increase structural $\mathrm{KM}$ infrastructure positively affects SMEs Innovativeness by $17.9 \%$. This result indicates that Cultural KM infrastructure more significant effect on the SMEs Innovativeness in Benue State, Nigeria.

\section{DISCUSSION}

Pearson correlation of technological KM infrastructure and SMEs innovativeness revealed that the calculated correlation coefficient $r=0.429$ at 0.05 significance level is positive and significant. Also, the two-tailed test conducted to access the significance level of the value of correlation coefficient yields a Pvalue of 0.000 which was significant at 0.05 level. This result indicates that technological KM infrastructure is significantly related with SMEs Innovativeness. The result of multiple regression analysis also confirmed significant effect of technological KM infrastructure on SMEs Innovativeness in Benue state, Nigeria. The pvalue (0.012) was lower than the significance level 0.05 . This can be statistically given as P-value $0.012<$ $\alpha=0.05$. This result is consistent with the findings of Hajir, Obeidat, Al-dalahmeh and Masa'deh [27] which showed that there is a statistically significant impact of technology on innovation. The findings also supports the result of Amundsen, et al. [6] which revealed that technological tools such as information and communication technology can improve KM processes capability, which is a significant predictor of firm's innovativeness.

From the second hypothesis, Pearson correlation of cultural KM infrastructure and SMEs innovativeness revealed that the calculated correlation coefficient $r=0.518$ at 0.05 significance level is positive and significant. Also, the two-tailed test conducted to access the significance level of the value of correlation coefficient yields a P-value of 0.000 which was significant at 0.05 level. This result indicates that cultural KM infrastructure is significantly related with SMEs Innovativeness. The result of multiple regression analysis also confirmed significant effect of cultural KM infrastructure on SMEs Innovativeness in Benue state, Nigeria. The p-value (0.000) was lower than the significance level 0.05 . This can be statistically given as $\mathrm{P}$-value $0.000<\alpha=0.05$. This finding corresponds with the results from studies by Kambiz and Aslan [53] and Büschgens, et al. [46] who found organizational culture as having significant effect on firm innovativeness.

Finally, from the third hypothesis, Pearson correlation of structural KM infrastructure and SMEs innovativeness revealed that the calculated correlation coefficient $r=0.705$ at 0.05 significance level is positive and significant. Also, the two-tailed test conducted to access the significance level of the value of correlation coefficient yields a P-value of 0.000 which was significant at 0.05 level. This result indicates that structural KM infrastructure is significantly related with SMEs Innovativeness. The result of multiple regression analysis also confirmed significant effect of structural KM infrastructure on SMEs Innovativeness in Benue state, Nigeria. The p-value (0.007) was lower than the significance level 0.05 . This can be statistically given as $\mathrm{P}$-value $0.007<\alpha=0.05$. This result corroborates with the finding of Matin and Sabagh [35] who found decentralized organizational structure positively related to innovativeness. It opposes the finding by Hajir, Obeidat, Al-dalahmeh and Masa'deh [4] examined the impact of organizational structure on innovation in the telecommunication industry, and found a negative and insignificant impact of organizational structure on innovation.

\section{Implications of findings to owners and managers of smes in benue state}

With the evident fierce struggle for competitive advantage in the SMEs industry in Benue state, the findings of the current study can aid the SMEs in determining what factors can contribute to the enhancement of innovativeness which is the backbone of competitive advantage. The findings of this study imply that adequate investment on KM infrastructural capabilities can improve innovativeness. The finding of this study is a prompt to SMEs in Benue state to the importance of KM infrastructural capability and the necessity of adopting appropriate strategies that will aid the procurement and utilization of these infrastructures in accordance to their goals.

\section{CONCLUSION}

The main objective of this study was to examine the relationship between KM infrastructural capabilities and SMEs innovativeness. From the study findings, it is concluded that $\mathrm{KM}$ infrastructural dimensions (technology, culture and structure) are all significantly related with SMEs innovativeness and that they all affect SMEs innovativeness. This study also concludes that organizational culture has the highest effect on SMEs innovativeness followed by technology while organizational structure has a low effect on SMEs innovativeness, though still significant. The low effect of organizational structure on SMEs innovativeness could be explained by variations in organizational structural designs with different effects on innovativeness.

\section{RECOMMENDATIONS}

This study found technological KM infrastructure as a vital determinant of SMEs innovativeness. Therefore, it is recommended that SMEs need to double their support for the use of technological facilities and develop the desired trainings for the operation of technological facilities.

Organizational culture is also found to significantly contribute to innovativeness of SMEs. This study therefore, recommends that SMEs in Benue state 
should absorb suitable organizational culture that sustains innovativeness.

This study found organizational structure as KM infrastructural dimension facilitating SMEs innovativeness. Prior studies that reached similar findings approved of decentralized structure as it favors innovativeness [59, 60]. This study then suggests a flatter structure for SMEs so as to speed knowledge sharing in a way that information will be rapid and timely.

\section{REFERENCES}

1. Wheelen, T. L., Hunger, J. D., Hoffman, A. N., Bamford, C. E. (2015). Strategic Management and Business Policy: Globalization, Innovation and Sustainability. Upper Saddle River, NJ: Prentice Hall.

2. Nielsen, A. P.(2006). Understanding dynamic capabilities through knowledge management. Journal of Knowledge Management, 10(4): 59-71.

3. Chen, Q.(2011). Towards the Application Framework of Innovation-Based Knowledge Management System with Information Technology, Advances in Computer Science, Environment, Eco informatics, and Education, 218, 407-412.

4. Hajir, J., Obeidat, B. Y., Al-dalahmeh, M. A., \& Masa'deh, R. (2015). The role of knowledge management infrastructure in enhancing innovation at mobile telecommunication companies in Jordan. European Journal of Social Sciences, 50(3), 313-330.

5. Cantner, U., Joel, K., \& Schmidt, T. (2011). The effects of knowledge management on innovative success-An empirical analysis of German firms. Research Policy, 40(10), 1453-1462.

6. Gressgård, L. J., Amundsen, O., Aasen, T. M., \& Hansen, K. (2014). Use of information and communication technology to support employeedriven innovation in organizations: a knowledge management perspective. Journal of Knowledge Management.

7. Ahmadi, A. A., Momeni, M., \& Ahmadi, F. (2013). Required Infrastructures for Implementation of Knowledge Management System in the Masjed Soleyman Oil and Gas Production Company. Interdisciplinary Journal of Contemporary Research in Business, 5(2), 60-72.

8. Cardoso, L., \& Gomes, A. D. (2011). Knowledge management and innovation: Mapping the use of technology in organizations. In Technology for creativity and innovation: Tools, techniques and applications (pp. 237-266). IGI Global.

9. Masa'deh, R. E., Almajali, D. A., Alrowwad, A. A., \& Obeidat, B. (2019). The role of knowledge management infrastructure in enhancing job satisfaction: a developing country perspective. Interdisciplinary Journal of Information, Knowledge \& Management, 14.
10. Gold, A. H., Malhotra, A., \& Segars, A. H. (2001). Knowledge management: An organizational capabilities perspective. Journal of management information systems, 18(1), 185-214.

11. Zaied, A. N. H. (2012). An integrated knowledge management capabilities framework for assessing organizational performance. International Journal of Information Technology and Computer Science, 4(2), 1-10.

12. Imran, M. K. (2014). Impact of knowledge management infrastructure on organizational performance with moderating role of $\mathrm{KM}$ performance: An empirical study on banking sector of Pakistan. In Information and Knowledge Management (Vol. 4, No. 8, pp. 85-98).

13. Shannak, R., Maqableh, M., \& Tarhini, A. (2017). The impact of knowledge management on job performance in higher education. Journal of Enterprise Information Management.

14. Sivagiri, N.(2018). The effects of knowledge management infrastructure capability on knowledge management effectiveness of Doctors: An empirical study. Journal of Management, 5(5): 218-231.

15. Hayes, R., Pisano, G., Upton, D., Wheelwright, S.(2005). Operations, Strategy and Technology: Pursuing the Competitive edge. In United Kingdom: Lightning Source UK ltd.

16. Goh, A. L.(2005). Harnessing Knowledge for Innovation: an Integrated Management Framework. Journal of Knowledge Management, 9(4): 6-18.

17. Mazzarol, T.W. (2002). Innovativeness in Small Firms: An Exploratory Study of the Perspectives of Growth Oriented Owner-Managers. International Journal of Innovation Management, Policy \& Practice, 4(1-3): 30-40.

18. Gibb, A. A.(2000). SME Policy, Academic Research and the Growth of Ignorance, Mythical Concepts, Myths, Assumptions, Rituals and Confusions. International Small Business Journal, 18(3): 13-35.

19. World Bank.(2014). SME's Contributions to Employment Report,

20. Chen, C.J., Huang, J.W.(2007). How Organizational Climate and Structure Affect Knowledge Management: The Social Interaction Perspective. International Journal of Information Management, 27(2): 104-118.

21. Aujirapongpan, S., Vadhanasindhu, P., Chandrachai, A., Cooparat, P.(2010). Indicators of Knowledge Management Capability for KM Effectiveness. Vine, 40(2): 138-203.

22. Plessis, M.(2007). The Role of Knowledge Management in Innovation. Journal of Knowledge Management, 11(4): 20-29.

23. Lin, H.F.(2013). The Effects of Knowledge Management Capabilities and Partnership Attributes on the Stage-based E-business Diffusion. Internet Research, 23(4): 439-464. 
24. Liao, C., Wang, H.Y., Chuang, S.H., Shih, M.-L., Liu, C.C.(2010). Enhancing Knowledge Management for R\&D Innovation and Firm Performance: An Integrative View. African Journal of Business Management, 4(14): 3026-3038.

25. Zaied, A. N. H., Hussein, G. S., Hassan, M. M. (2012). The Role of Knowledge Management in Enhancing Organizational Performance. International Journal of Information Engineering and Electronic Business, 4(5): 27.

26. King, W. R.(2009). Knowledge Management and Organizational learning. Annals of Information Systems, Springer: USA.

27. Hajir, J. A., Obeidat, B. Y., Al-dalahmeh, M. A., Masa'deh, R.(2015). The Role of Knowledge Management Infrastructure in Enhancing Innovation at Mobile Telecommunication Companies in Jordan. European Journal of Social Sciences, 50(3): 313-330.

28. Hassanien, A., Dale, C. (2013). Facilities Management and Development for Tourism, Hospitality and Events (1st edition), Oxfordshire: CABI.

29. Sun, P.(2010). Five Critical Knowledge Management Organizational Themes. Journal of Knowledge management, 14(4): 507-523.

30. Theriou, N., Maditinos, D., Theriou, G.(2010). Knowledge Management Enabler Factors and Firm Performance: An Empirical Research of the Greek Medium and Large Firms. Paper Presented at the International Conference on Applied Business \& Economics.

31. Kanaan, R., Masa'deh, R., Gharaibeh, A.(2013). The Impact of Knowledge Sharing Enablers on Knowledge Sharing Capability: An Empirical Study on Jordanian Telecommunication Firms', European Scientific Journal, 9(22), 237-258.

32. Masa'deh, R., Tarhini, A., Al-Dmour, R., Obeidat, B.(2015b). Strategic IT-Business Alignment as Managers' Exploitative Strategies', European Scientific Journal, 11(7): 437- 457.

33. Pannu, H.(2017). The impact of knowledge management infrastructure on organizational performance in SMEs. International Journal of Human Resource \& Industrial Research, 4(2): 2631.

34. Pandey, S. C., \& Dutta, A. (2013). Role of knowledge infrastructure capabilities in knowledge management. Journal of knowledge management.

35. Matin, E. K., \& Sabagh, P. (2015). Effects of Knowledge Management Capabilities on Organizational Performance in Iranian Export Companies. Mediterranean Journal of Social Sciences, 6(2), 240.

36. Majchrzak, A., Rice, R. E., Malhotra, A., King, N., $\&$ Ba, S. (2000). Technology adaptation: The case of a computer-supported inter-organizational virtual team. MIS quarterly, 569-600.

37. Rasula, J., Vuksic, V. B., \& Stemberger, M. I. (2012). The impact of knowledge management on organisational performance. Economic and Business Review for Central and South-Eastern Europe, 14(2), 147.

38. Martín- de Castro, G., López- Sáez, P., DelgadoVerde, M., Donate, M. J., \& Guadamillas, F. (2011). Organizational factors to support knowledge management and innovation. Journal of knowledge management.

39. Ho, C. F., Hsieh, P. H., \& Hung, W. H. (2014). Enablers and processes for effective knowledge management. Industrial Management \& Data Systems.

40. Iftikhar, Z., Eriksson, I. V., \& Dickson, G. W. (2003). Developing an instrument for knowledge management project evaluation. Electronic Journal of Knowledge Management, 1(1), 55-62.

41. Islam, M. Z., Jasimuddin, S. M., \& Hasan, I. (2015). Organizational culture, structure, technology infrastructure and knowledge sharing. Vine.

42. Masa'deh, R. E., Almajali, D. A., Alrowwad, A. A., \& Obeidat, B. (2019). The role of knowledge management infrastructure in enhancing job satisfaction: a developing country perspective. Interdisciplinary Journal of Information, Knowledge \& Management, 14.

43. Ghani, K. A., Jayabalan, V., \& Sugumar, M. (2002). Impact of advanced manufacturing technology on organizational structure. The Journal of High Technology Management Research, 13(2), 157-175.

44. Masa'deh, R. E. (2016). The role of knowledge management infrastructure in enhancing job satisfaction at Aqaba five star hotels in Jordan.

45. Laforet, S. (2011). A framework of organisational innovation and outcomes in SMEs. International Journal of Entrepreneurial Behavior \& Research.

46. Büschgens, T., Bausch, A., \& Balkin, D. B. (2013). Organizational culture and innovation: A metaanalytic review. Journal of product innovation management, 30(4), 763-781.

47. Mills, A. M., \& Smith, T. A. (2011). Knowledge management and organizational performance: a decomposed view. Journal of knowledge management.

48. Camisón, C., \& Villar-López, A. (2011). Nontechnical innovation: Organizational memory and learning capabilities as antecedent factors with effects on sustained competitive advantage. Industrial Marketing Management, 40(8), 1294-1304.

49. Akram, K., Siddiqui, S. H., Nawaz, M. A., Ghauri, T. A., \& Cheema, A. K. H. (2011). Role of knowledge management to bring innovation: an integrated approach. Cell, 92(333), 6183035.

50. Okatan, K. (2012). Managing knowledge for innovation and intra networking: a case study. Procedia-Social and Behavioral Sciences, 62, 59-63. 
51. Shikanda, E. W., \& Okibo, B. W. (2011). Effects of organizational culture on innovation in services industry: A case study of Postal Corporation of Kenya.

52. Obeidat, B. Y., \& Tarhini, A. (2016). A Jordanian empirical study of the associations among transformational leadership, transactional leadership, knowledge sharing, job performance, and firm performance. Journal of Management Development.

53. Abdi, K., \& Senin, A. A. (2014). Investigation on the impact of organizational culture on organization innovation. Journal of Management Policies and Practices, 2(2), 1-10.

54. Argyres, N. S., \& Silverman, B. S. (2004). R\&D, organization structure, and the development of corporate technological knowledge. Strategic Management Journal, 25(8- 9), 929-958.

55. Lai, Y. (2013). The moderating effect of organizational structure in knowledge management for international ports in Taiwan. International journal of computer and information technology, 2(2), 240-246.
56. Syvertsen, C.(2008). What is the Future of Business Schools? European Business Review.

57. Liao, C., Wang, H. Y., Chuang, S. H., Shih, M. L., \& Liu, C. C. (2010). Enhancing knowledge management for R\&D innovation and firm performance: An integrative view. African Journal of Business Management, 4(14), 3026.

58. Hung, R. Y. Y., Lien, B. Y. H., Yang, B., Wu, C. M., \& Kuo, Y. M. (2011). Impact of TQM and organizational learning on innovation performance in the high-tech industry. International business review, 20(2), 213-225.

59. Lee, H., \& Choi, B. (2003). Knowledge management enablers, processes, and organizational performance: An integrative view and empirical examination. Journal of management information systems, 20(1), 179-228.

60. Sin, L. Y., \& Alan, C. B. (2000). How does marketing effectiveness mediate the effect of organizational culture on business performance? The case of service firms. Journal of services marketing. 